\title{
Integration, Mobility, and Human Capital Formation
}

\author{
Alexander Haupt \\ Silke Uebelmesser
}

CESIFO WORKING PAPER No. 3190

CATEGORY 4: LABOUR MARKETS

SEPTEMBER 2010

\author{
An electronic version of the paper may be downloaded \\ - from the SSRN website: \\ - from the RePEc website: \\ - from the CESifo website: \\ www.SSRN.com \\ Www.RePEc.org \\ www.CESifo-group.org/wp
}




\title{
Integration, Mobility, and Human Capital Formation
}

\begin{abstract}
In this note, we show that labour market integration can be a double-edged sword. In the presence of local human capital externalities, integration and the ensuing agglomeration of skilled labour can cause a decline in human capital and the total wage sum (net of education costs). In particular, integration depresses the incentives for some talented but immobile individuals to become skilled.
\end{abstract}

JEL-Code: F22, J24, J61, R23.

Keywords: human capital, migration, labour market integration, agglomeration.

\author{
Alexander Haupt \\ Plymouth Business School \\ University of Plymouth \\ Drake Circus \\ UK - Plymouth, PL4 8AA \\ alexander.haupt@plymouth.ac.uk
}

\author{
Silke Uebelmesser \\ Center for Economic Studies at the \\ University of Munich \\ Schackstrasse 4 \\ Germany-80539 Munich \\ uebelmesser@lmu.de
}

\section{September 2010}

We are grateful to Christoph Lülfesmann and Tobias Seidel for very helpful comments. We have also benefited from discussions at the Norwegian-German Seminar on Public Economics, at an annual meeting of the Committee for Population Economics of the German Economic Association, and at the annual conference of the International Institute of Public Finance. An initial draft was written while A. Haupt was visiting the Center for Economic Studies at the University of Munich. He is grateful to the members of CES and the Economics Department for their hospitality and stimulating discussions, and to CES for financial support for this research visit. 


\section{Motivation}

According to the conventional wisdom, labour market integration promotes overall efficiency. Integration enables mobile skilled workers to get employed where they are most productive, and induces agglomeration of skill-intensive industries, thereby enhancing aggregate income. In this note we qualify this line of reasoning. We show that in the presence of local human capital externalities, labour market integration and the ensuing agglomeration of skilled workers can cause a decline in human capital and the total wage sum (net of education costs). In particular, agglomeration reduces the incentives for some talented but immobile individuals to invest in education.

Thus integration affects not only the location of human capital, but also its overall stock. This feature distinguishes our note from the literature on the new economic geography, which considers total human capital as given when analysing the implications of integration (e.g., the recent papers Gallo, 2010; Pflüger and Südekum, 2008). By endogenising human capital formation, our approach is somewhat closer to that in the literature on the brain drain, which explores how the opportunity of emigrating to rich countries affects human capital in poor countries (e.g., Stark et al., 1998). Our focus is different, however: we are interested in the impact of integration and the ensuing agglomeration on two ex-ante identical regions, and analyse the implications for overall welfare in the two regions together.

\section{The Model}

Regions and Industries Consider two ex-ante identical regions, each with a population of unity. In each region, a continuum of symmetric firms in the interval $[0,1]$ produces a high-quality good with skilled workers only. The production technology is characterised by constant returns-to-scale at the firm level and increasing returns to scale 
at the regional industry level. More precisely, the output of firm $k$ in region $i$ is

$$
y_{i}^{k}=A\left(H_{i}\right) \cdot h_{i}^{k}
$$

where $h_{i}^{k}$ and $H_{i}, H_{i}=\int_{0}^{1} h_{i}^{k} d k$, denote the number of skilled workers employed by firm $k$ in region $i$ and the regional human capital stock, respectively. Regional productivity $A\left(H_{i}\right)$ is a positive, increasing and strictly concave function of the human capital employed in the regional industry, i.e., $A(0)>0, \partial A(H) / \partial H_{i}>0$, and $\partial^{2} A\left(H_{i}\right) / \partial H_{i}^{2}<0$.

The product's world market price is normalised to unity. Then profit maximisation implies that the regional skilled wage $w_{i}$ equals each firm's marginal product $A\left(H_{i}\right)$, which is exogenous from the perspective of a single firm. The resulting inverse aggregate demand for skilled labour in region $i$

$$
w_{i}=\frac{\partial y_{i}^{k}}{\partial h_{i}^{k}}=A\left(H_{i}\right)
$$

is an increasing and concave function (see Figure 1). These properties stem from a human capital externality and set the stage for a simple agglomeration mechanism.

Figure 1: Labour Market Equilibrium

Figure 1a) Non-Integrated Economy

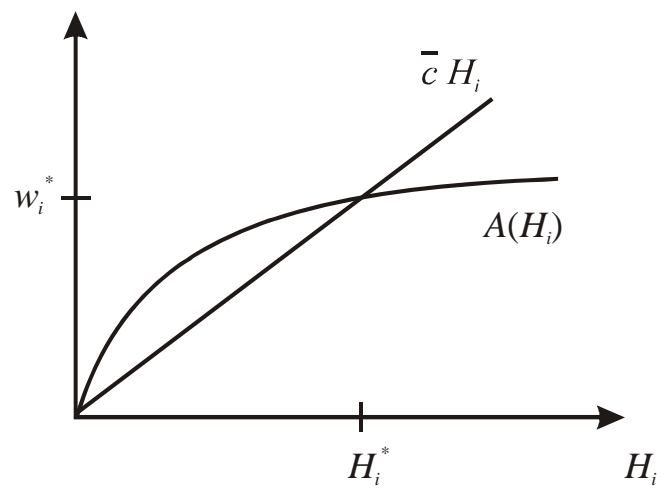

Figure 1b) Integrated Economy

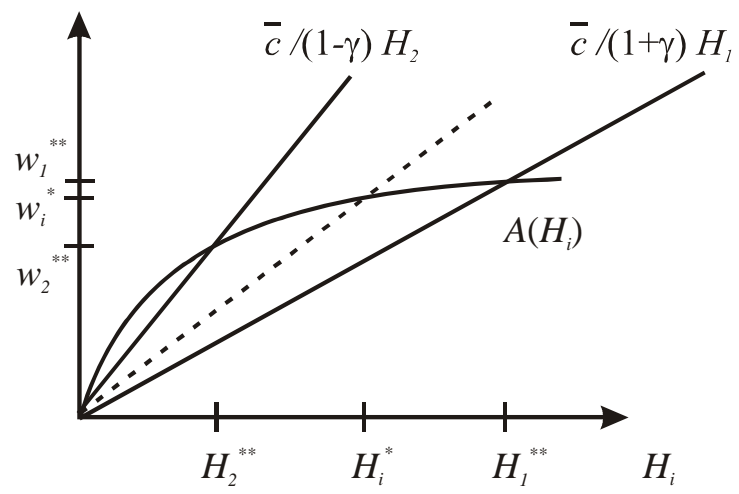


Individual Characteristics and Options Individuals differ in their ability and mobility. Ability is captured by individual education costs, i.e., the costs of becoming a skilled worker. Let $c_{i}^{j}$ denote the education costs of native $j$ of region $i$, and let us assume that these education $\operatorname{costs} c_{i}^{j}$ are uniformly distributed in the interval $[0, \bar{c}]$, $\bar{c}>\left.A\left(H_{i}\right)\right|_{H_{i}=2}{ }^{1}$

We further assume that $\gamma$ natives of each region are perfectly mobile and can move to the other region at no cost, with $\gamma \in(0,1)$. By contrast, $(1-\gamma)$ natives are perfectly immobile and will never leave their home region. The distribution of education costs is the same across the mobile and immobile groups.

Individuals make two decisions. Firstly, each individual chooses whether to become skilled or not. While skilled individuals can work for firms and earn wage income, unskilled individuals are not employable and cannot receive any income (and thus will be ignored in the following). Secondly, if labour markets are integrated, each individual chooses whether to stay in their home region or to migrate to the other region.

\section{Education, Migration, and Labour Markets}

Non-Integrated Labour Markets Consider the benchmark case of non-integrated labour markets. Then, individuals can decide on their education only. Native $j$ of region $i$ will become skilled if and only if the skilled wage $w_{i}$ exceeds the individual education $\operatorname{costs} c_{i}^{j}$, i.e., $w_{i} \geq c_{i}^{j}$. Thus, the aggregate supply of skilled workers in region $i$ is

$$
S_{i}=\frac{w_{i}}{\bar{c}} \quad \Leftrightarrow \quad w_{i}=\bar{c} S_{i}
$$

Jointly, the supply function (3) and the demand function (2) determine the stable

\footnotetext{
${ }^{1}$ The assumption $\bar{c}>\left.A\left(H_{i}\right)\right|_{H_{i}=2}$ ensures that some individuals remain unskilled.
} 
labour market equilibrium (see Figure 1a), ${ }^{2}$ implicitly defined by

$$
H_{i}^{*}=S_{i}^{*}, \quad A\left(H_{i}^{*}\right)=\bar{c} H_{i}^{*}, \quad \text { and } \quad w_{i}^{*}=\bar{c} H_{i}^{*} .
$$

Integrated labour markets Next, consider the case of integrated labour markets. There exists an agglomeration equilibrium with a high-wage ('winning') region and a lowwage ('losing') region, referred to as region 1 and 2 : that is, $w_{1}>w_{2}$. Since moving to the winning region enables individuals to reap higher returns on human capital, education and migration choices are now intertwined, with the decision on education depending on both ability and mobility.

Mobile natives of the losing region will move to the high-wage region if they are skilled, and will thus base their education decision on the skilled wage in the winning region. That is, mobile individual $j$ of region 2 will become skilled if and only if the wage $w_{1}$ exceeds the education $\operatorname{costs} c_{2}^{j}$, i.e., $w_{1} \geq c_{2}^{j}$. Thus, the skilled labour supply of immigrants in the winning region is $M=\gamma w_{1} / \bar{c}$. In contrast to the mobile individuals, immobile individuals of the losing region stay put. They will become skilled if and only if the wage $w_{2}$ exceeds their education $\operatorname{costs} c_{2}^{j}$, i.e., $w_{2} \geq c_{2}^{j}$. Overall, the number of skilled workers native to the losing region is $S_{2}=\left[\gamma w_{1}+(1-\gamma) w_{2}\right] / \bar{c}$, of whom $S_{2}-M=(1-\gamma) w_{2} / \bar{c}$ stay in region 2 .

In the winning region, individuals have no incentive to leave, and the domestic labour supply function of the natives remains the same as in the case of non-integrated markets, i.e., $S_{1}=w_{1} / \bar{c}$. Thus the aggregate supply in the winning region is $S_{1}+M=$

\footnotetext{
${ }^{2}$ The stability of the equilibrium follows directly from the concavity of the demand function (2) and the linearity of the supply function (3).
} 
$(1+\gamma) w_{1} / \bar{c}$. To sum up,

$$
\begin{aligned}
& S_{1}+M=(1+\gamma) \frac{w_{1}}{\bar{c}} \quad \Leftrightarrow \quad w_{1}=\frac{\bar{c}}{(1+\gamma)}\left(S_{1}+M\right) \quad \text { and } \\
& S_{2}-M=(1-\gamma) \frac{w_{2}}{\bar{c}} \quad \Leftrightarrow \quad w_{2}=\frac{\bar{c}}{(1-\gamma)}\left(S_{2}-M\right) .
\end{aligned}
$$

The demand for skilled labour in each region is still given by (2). Jointly, the regional supply and demand functions determine a stable agglomeration equilibrium (see Figure 1b), with

$$
\begin{array}{lll}
H_{1}^{* *}=S_{1}^{* *}+M^{* *}, & A\left(H_{1}^{* *}\right)=\frac{\bar{c}}{(1+\gamma)} H_{1}^{* *}, \quad w_{1}^{* *}=\frac{\bar{c}}{(1+\gamma)} H_{1}^{* *}, \\
H_{2}^{* *}=S_{2}^{* *}-M, & A\left(H_{2}^{* *}\right)=\frac{\bar{c}}{(1-\gamma)} H_{2}^{* *}, \quad w_{2}^{* *}=\frac{\bar{c}}{(1-\gamma)} H_{2}^{* *} .
\end{array}
$$

Comparison Labour market integration and human capital externalities trigger the agglomeration of skilled labour, boosting productivity and the skilled wage in the winning region. As a result, the incentive to invest in education increases not only for the natives of region 1 , but also for the mobile natives of region 2 , who can easily move to the high-wage region. The share of skilled workers among these groups increases from $w_{i}^{*} / \bar{c}$ to $w_{1}^{* *} / \bar{c}$, and more skilled workers are employed in the winning region.

In the losing region, the outflow of human capital depresses productivity and the skilled wage. Consequently, fewer immobile natives find it beneficial to become skilled, and the share of skilled workers among them drops from $w_{i}^{*} / \bar{c}$ to $w_{2}^{* *} / \bar{c}$. Thus, fewer skilled individuals work in the losing region. Importantly, agglomeration distorts the education decision. Talented but immobile natives shy away from education, whereas more of the less talented but mobile individuals become skilled.

\section{Impact on Human Capital and the Wage Sum}

We are now able to assess the overall impact of integration on total human capital $H_{1+2}=H_{1}+H_{2}$ and the total wage sum $W_{1+2}=w_{1} H_{1}+w_{2} H_{2}$. There is no need to 
consider the net wage sum, i.e., the wage sum minus education costs, separately because the net wage sum exactly equals one half of the wage sum. ${ }^{3}$ Our comparison of the stable equilibrium in the benchmark case and the agglomeration equilibrium is summarised in

Proposition 1 Labour market integration leads to one of the following three outcomes: (i) Total human capital increases, i.e., $H_{1+2}^{* *} \geq H_{1+2}^{*}$. Then, the total wage sum also rises, i.e., $W_{1+2}^{* *}>W_{1+2}^{*}$. (ii) Total human capital declines, but the total wage sum increases, i.e., $H_{1+2}^{* *}<H_{1+2}^{*}$ and $W_{1+2}^{* *}>W_{1+2}^{*}$. (iii) The total wage sum decreases, i.e., $W_{1+2}^{* *} \leq W_{1+2}^{*}$. Then, human capital also declines, i.e., $H_{1+2}^{* *}<H_{1+2}^{*}$.

Proof. See the Appendix.

If agglomeration causes a substantial productivity gain and wage rise in region 1 relative to the losses in region 2 , then integration strengthens the overall incentives to invest in education, and total human capital grows. If this happens, the total wage sum surges for sure, and so does the net wage sum. This scenario is illustrated in Figure 2a, with an almost linear productivity function $A(H)$.

Importantly, the (net) wage sum may increase even if human capital declines. So we cannot infer from the fact that there are fewer skilled people that there are no overall benefits from agglomeration. In this scenario, the wage rise for some individuals not only compensates for the loss of others, but also makes up for the fall in the total number of skilled workers.

However, if the wage decline in region 2 is sufficiently drastic relative to the improvement in region 1 , the (net) wage sum will decrease, and such a drop will always be accompanied by a decrease in human capital. This scenario is illustrated in Figure 2b, which shows a strongly curved productivity function $A(H)$.

\footnotetext{
${ }^{3}$ As education costs of those who become skilled are uniformly distributed in the interval $\left[0, w_{i}\right]$, the average education costs of skilled workers is $0.5 w_{i}$.
} 
Figure 2: Impact of Integration on Human Capital and Wages
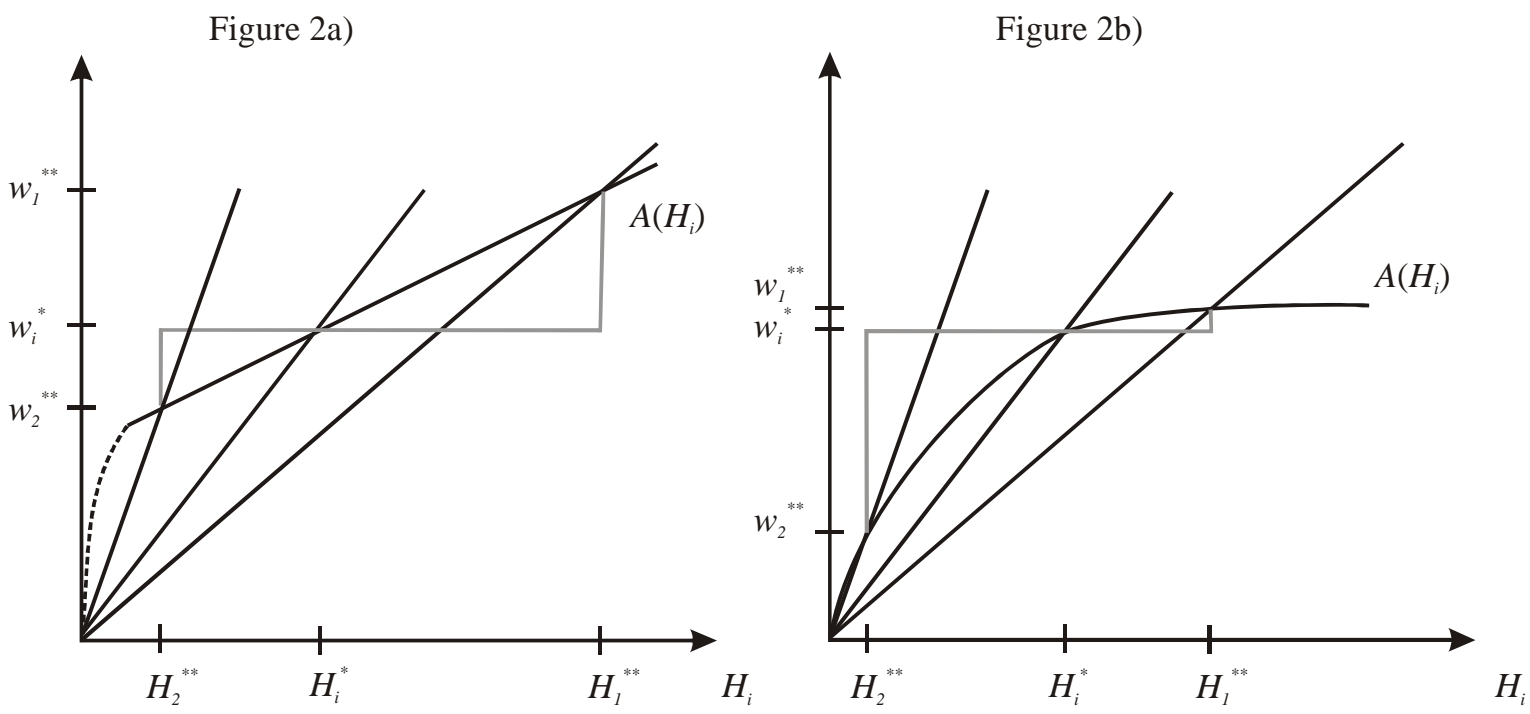

Our second proposition sums up how mobility affects the benefits from agglomeration.

Proposition 2 There exists a critical value $\gamma^{\text {crit }}<1$ such that integration boosts total human capital and the total wage sum (i.e., $H_{1+2}^{* *}>H_{1+2}^{*}$ and $W_{1+2}^{* *}>W_{1+2}^{*}$ ) if $\gamma>\gamma^{\text {crit }}$.

Proof. See the Appendix.

Integration will always generate overall gains if individuals are sufficiently mobile: that is, if enough individuals are able to join the winners. However, these overall benefits conceal severe distributional conflicts. The larger the share $\gamma$ of mobile individuals is, the greater the income gains of those employed in the winning region, but also the greater the income losses of those working in the losing region.

\section{Concluding Remarks}

The outlook for the losing region would be less gloomy if skilled workers emigrated with a probability smaller than one, as is often assumed in the literature on brain drain (e.g., Stark and Wang, 2002). This modification would dilute the impact of integration, but it 
would not change the effects qualitatively. Still, labour market integration can depress human capital and total labour income. As argued, a decline in human capital itself does not necessarily indicate that the total wage sum has also fallen. The complex picture that emerges from even such a simple model cautions against simple policy recommendations.

\section{Appendix}

Proof of Proposition 1: Part (i): First, we show that $H_{1+2}^{* *}>H_{1+2}^{*}$ is possible. To this end, we consider the boundary case where $A\left(H_{i}\right)=d+\delta H_{i}$ for $H \in[\underline{H}, \bar{H}]$, $\underline{H}<H_{2}^{* *}, \bar{H}>H_{1}^{* *}$, and $\bar{c}>d+2 \delta$ (see Figure $2 \mathrm{~b}$ ). Then, $H_{1+2}^{*}=2 d /(\bar{c}-\delta)$, $H_{1}^{* *}=[(1+\gamma) d] /[\bar{c}-(1+\gamma) \delta]$, and $H_{2}^{* *}=[(1-\gamma) d] /[\bar{c}-(1-\gamma) \delta]$, implying that $H_{1+2}^{* *}>H_{1+2}^{*} \Leftrightarrow \gamma^{2} \delta \bar{c}>0$. Finally, we can slightly manipulate $A\left(H_{i}\right)$ such that $A\left(H_{i}\right)$ is strictly concave and still yields $H_{1+2}^{* *}>H_{1+2}^{*}$.

Second, we show that $H_{1+2}^{* *} \geq H_{1+2}^{*} \Rightarrow W_{1+2}^{* *}>W_{1+2}^{*}$. Note that

$$
\begin{aligned}
W_{1+2}^{* *} & =(1+\gamma) \frac{\left(w_{1}^{* *}\right)^{2}}{\bar{c}}+(1-\gamma) \frac{\left(w_{2}^{* *}\right)^{2}}{\bar{c}} \\
& >(1+\gamma)^{2} \frac{\left(w_{1}^{* *}\right)^{2}}{2 \bar{c}}+(1-\gamma)^{2} \frac{\left(w_{2}^{* *}\right)^{2}}{2 \bar{c}}+(1+\gamma)(1-\gamma) \frac{w_{1}^{* *} w_{2}^{* *}}{\bar{c}}=\frac{\bar{c}}{2}\left(H_{1+2}^{* *}\right)^{2} \\
& \Leftrightarrow\left(w_{1}^{* *}-w_{2}^{* *}\right)^{2}>0
\end{aligned}
$$

Thus, $W_{1+2}^{* *}>\left[\bar{c}\left(H_{1+2}^{* *}\right)^{2}\right] / 2$. We also know that $H_{1+2}^{* *} \geq H_{1+2}^{*} \Leftrightarrow\left[\bar{c}\left(H_{1+2}^{* *}\right)^{2}\right] / 2 \geq$ $\left[\bar{c}\left(H_{1+2}^{*}\right)^{2}\right] / 2=2 \frac{\left(w_{i}^{*}\right)^{2}}{\bar{c}}=W_{1+2}^{*}$. To sum up, $W_{1+2}^{* *}>\left[\bar{c}\left(H_{1+2}^{* *}\right)^{2}\right] / 2$ and, if $H_{1+2}^{* *} \geq$ $H_{1+2}^{*},\left[\bar{c}\left(H_{1+2}^{* *}\right)^{2}\right] / 2 \geq W_{1+2}^{*}$. Hence, $H_{1+2}^{* *} \geq H_{1+2}^{*} \Rightarrow W_{1+2}^{* *}>W_{1+2}^{*}$.

Part (iii): First, the logical relationship $H_{1+2}^{* *} \geq H_{1+2}^{*} \Rightarrow W_{1+2}^{* *}>W_{1+2}^{*}$ implies $W_{1+2}^{* *} \leq W_{1+2}^{*} \Rightarrow H_{1+2}^{* *}<H_{1+2}^{*}$. Second, we show that $W_{1+2}^{* *}<W_{1+2}^{*}$ is possible. Comparing equilibrium values yields $w_{1}^{* *}>w_{i}^{*}>w_{2}^{* *}$. Thus we can write $w_{1}^{* *}=w_{i}^{*}+\varepsilon$ and $w_{2}^{* *}=w_{i}^{*}-\eta$, with $\varepsilon>0$ and $0<\eta<w_{i}^{*}$. By choosing $A(H)$ appropriately, $\varepsilon$ can be infinitesimally small. Moreover, $H_{1}^{* *}>(1+\gamma) H_{i}^{*}$, $\lim _{\varepsilon \rightarrow 0} H_{1}^{* *}=(1+\gamma) H_{i}^{*}$, and 
$H_{2}^{* *}<(1-\gamma) H_{i}^{*}$ follows from (4), (7), and (8). Thus, $\lim _{\varepsilon \rightarrow 0} w_{1}^{* *} H_{1}^{* *}=(1+\gamma) w_{i}^{*} H_{i}^{*}$ and $w_{2}^{* *} H_{2}^{* *}<(1-\gamma)\left(w_{i}^{*}-\eta\right) H_{i}^{*}$, implying that $\lim _{\varepsilon \rightarrow 0} W_{1+2}^{* *}<2 w_{i}^{*} H_{i}^{*}-(1-\gamma) \eta H_{i}^{*}<$ $2 w_{i}^{*} H_{i}^{*}=W_{1+2}^{*}$.

Part (ii): By choosing $A(H)$ appropriately, we have $W_{1+2}^{* *}=W_{1+2}^{*}$, implying that $H_{1+2}^{* *}<H_{1+2}^{*}$. But then, we can slightly manipulate $A(H)$ such that $w_{1}^{* * n e w}=w_{1}^{* *}+\mu$ (with an infinitesimally small $\mu$ ), $W_{1+2}^{* * \text { new }}>W_{1+2}^{* *}=W_{1+2}^{*}$, and still $H_{1+2}^{* * \text { new }}<H_{1+2}^{*}$.

Proof of Proposition 2: As $w_{1}^{* *}>w_{i}^{*}$, we can write $w_{1}^{* *}=w_{i}^{*}+\varepsilon, \varepsilon>0$. Jointly with $H_{1}^{* *}>(1+\gamma) H_{i}^{*}$, this leads to $W_{1+2}^{* *}>(1+\gamma)\left(w_{i}^{*}+\varepsilon\right) H_{i}^{*}$. Also, $(1+\gamma)\left(w_{i}^{*}+\varepsilon\right) H_{i}^{*}>$ $2 w_{i}^{*} H_{i}^{*} \Leftrightarrow \gamma>\left(w_{i}^{*}-\varepsilon\right) /\left(w_{i}^{*}+\varepsilon\right)$. As $W_{1+2}^{*}=2 w_{i}^{*} H_{i}^{*}$ and $\left(w_{i}^{*}-\varepsilon\right) /\left(w_{i}^{*}+\varepsilon\right)<1$, we can conclude that for all $\varepsilon>0, \exists \gamma^{\text {crit }}<1: W_{1+2}^{* *}>W_{1+2}^{*}$ for all $\gamma \geq \gamma^{\text {crit }}$.

\section{References}

[1] Gallo, F. (2010), Resisting Economic Integration when Industry Location is Uncertain, European Economic Review 54, 467-482.

[2] Pflüger, M., and J. Südekum (2008), Integration, Agglomeration and Welfare, Journal of Urban Economics 63, 544-566.

[3] Stark, O., C. Helmenstein, and A. Prskawetz (1998), Human Capital Depletion, Human Capital Formation, and Migration: A Blessing or a "Curse"?, Economics Letters 60, 363-367.

[4] Stark, O., and Y. Wang (2002), Inducing Human Capital Formation: Migration as a Substitute for Subsidies, Journal of Public Economics 86, 29-46. 


\section{CESifo Working Paper Series}

for full list see www.cesifo-group.org/wp

(address: Poschingerstr. 5, 81679 Munich, Germany, office@cesifo.de)

3128 Volker Meier and Helmut Rainer, On the Optimality of Joint Taxation for NonCooperative Couples, July 2010

3129 Ryan Oprea, Keith Henwood and Daniel Friedman, Separating the Hawks from the Doves: Evidence from Continuous Time Laboratory Games, July 2010

3130 Mari Rege and Ingeborg F. Solli, The Impact of Paternity Leave on Long-term Father Involvement, July 2010

3131 Olaf Posch, Risk Premia in General Equilibrium, July 2010

3132 John Komlos and Marek Brabec, The Trend of BMI Values by Centiles of US Adults, Birth Cohorts 1882-1986, July 2010

3133 Emin Karagözoğlu and Arno Riedl, Information, Uncertainty, and Subjective Entitlements in Bargaining, July 2010

3134 John Boyd, Gianni De Nicolò and Elena Loukoianova, Banking Crises and Crisis Dating: Theory and Evidence, July 2010

3135 Michael R. Baye, Dan Kovenock and Casper G. de Vries, The Herodotus Paradox, July 2010

3136 Martin Kolmar and Hendrik Rommeswinkel, Group Contests with Complementarities in Efforts, July 2010

3137 Carolina Manzano and Xavier Vives, Public and Private Learning from Prices, Strategic Substitutability and Complementarity, and Equilibrium Multiplicity, July 2010

3138 Axel Löffler, Gunther Schnabl and Franziska Schobert, Inflation Targeting by Debtor Central Banks in Emerging Market Economies, July 2010

3139 Yu-Fu Chen and Michael Funke, Global Warming and Extreme Events: Rethinking the Timing and Intensity of Environmental Policy, July 2010

3140 Lawrence M. Kahn, Labor Market Policy: A Comparative View on the Costs and Benefits of Labor Market Flexibility, July 2010

3141 Ben J. Heijdra, Jochen O. Mierau and Laurie S.M. Reijnders, The Tragedy of Annuitization, July 2010

3142 Erkki Koskela, Outsourcing Cost and Tax Progression under Nash Wage Bargaining with Flexible Outsourcing, July 2010 
3143 Daniel Osberghaus and Christiane Reif, Total Costs and Budgetary Effects of Adaptation to Climate Change: An Assessment for the European Union, August 2010

3144 Philip E. Graves, Benefit-Cost Analysis of Environmental Projects: A Plethora of Systematic Biases, August 2010

3145 Sabrina Di Addario and Daniela Vuri, Entrepreneurship and Market Size. The Case of Young College Graduates in Italy, August 2010

3146 Shoshana Amyra Grossbard and Alfredo Marvăo Pereira, Will Women Save more than Men? A Theoretical Model of Savings and Marriage, August 2010

3147 Jarko Fidrmuc, Time-Varying Exchange Rate Basket in China from 2005 to 2009, August 2010

3148 Ilja Neustadt and Peter Zweifel, Is the Welfare State Sustainable? Experimental Evidence on Citizens' Preferences for Redistribution, August 2010

3149 Marcus Dittrich and Andreas Knabe, Wage and Employment Effects of Non-Binding Minimum Wages, August 2010

3150 Shutao Cao, Enchuan Shao and Pedro Silos, Fixed-Term and Permanent Employment Contracts: Theory and Evidence, August 2010

3151 Ludger Woessmann, Cross-Country Evidence on Teacher Performance Pay, August 2010

3152 Lorenzo C. G. Pozzi, Casper G. de Vries and Jorn Zenhorst, World Equity Premium Based Risk Aversion Estimates, August 2010

3153 Volker Grossmann, Thomas M. Steger and Timo Trimborn, Dynamically Optimal R\&D Subsidization, August 2010

3154 Alexander Haupt, Tim Krieger and Thomas Lange, A Note on Brain Gain and Brain Drain: Permanent Migration and Education Policy, August 2010

3155 António Afonso and Christophe Rault, Long-run Determinants of Sovereign Yields, August 2010

3156 Franziska Tausch, Jan Potters and Arno Riedl, Preferences for Redistribution and Pensions. What can we Learn from Experiments?, August 2010

3157 Martin Kolmar and Andreas Wagener, Inefficient Group Organization as Optimal Adaption to Dominant Environments, August 2010

3158 Kai Carstensen, Klaus Wohlrabe and Christina Ziegler, Predictive Ability of Business Cycle Indicators under Test: A Case Study for the Euro Area Industrial Production, August 2010 
3159 Horst Rottmann and Timo Wollmershäuser, A Micro Data Approach to the Identification of Credit Crunches, August 2010

3160 Philip E. Graves, Appropriate Fiscal Policy over the Business Cycle: Proper Stimulus Policies Can Work, August 2010

3161 Michael Binder and Marcel Bluhm, On the Conditional Effects of IMF Program Participation on Output Growth, August 2010

3162 Michael Binder, Qianying Chen, and Xuan Zhang, On the Effects of Monetary Policy Shocks on Exchange Rates, August 2010

3163 Felix J. Bierbrauer, On the Optimality of Optimal Income Taxation, August 2010

3164 Nikolaus Wolf, Europe's Great Depression - Coordination Failure after the First World War, September 2010

3165 Dan Kovenock and Brian Roberson, Conflicts with Multiple Battlefields, September 2010

3166 Jean-Pierre Ponssard and Catherine Thomas, Capacity Investment under Demand Uncertainty. An Empirical Study of the US Cement Industry, 1994-2006, September 2010

3167 Jørgen Juel Andersen, Jon H. Fiva and Gisle James Natvik, Voting when the Stakes are High, September 2010

3168 Michael Hoel, Is there a Green Paradox?, September 2010

3169 Scott Alan Carson, Nineteenth Century US African-American and White Female Statures: Insight from US Prison Records, September 2010

3170 Gil S. Epstein, Yosef Mealem and Shmuel Nitzan, Political Culture and Discrimination in Contests, September 2010

3171 Sara Fisher Ellison, Jeffrey Greenbaum and Wallace P. Mullin, Diversity, Social Goods Provision, and Performance in the Firm, September 2010

3172 Silvia Dominguez-Martinez, Randolph Sloof and Ferdinand von Siemens, Monitoring your Friends, not your Foes: Strategic Ignorance and the Delegation of Real Authority, September 2010

3173 Marcus Dittrich and Beate Schirwitz, Union Membership and Employment Dynamics: A Note, September 2010

3174 Francesco Daveri, Paolo Manasse and Danila Serra, The Twin Effects of Globalization - Evidence from a Sample of Indian Manufacturing Firms, September 2010

3175 Florian Blöchl, Fabian J. Theis, Fernando Vega-Redondo and Eric O’N. Fisher, Which Sectors of a Modern Economy are most Central?, September 2010 
3176 Dag Morten Dalen, Marilena Locatelli and Steinar Strøm, Longitudinal Analysis of Generic Substitution, September 2010

3177 Armin Falk, Stephan Meier and Christian Zehnder, Did we Overestimate the Role of Social Preferences? The Case of Self-Selected Student Samples, September 2010

3178 Christian Fahrholz and Cezary Wójcik, The Bail-Out! Positive Political Economics of Greek-type Crises in the EMU, September 2010

3179 Klaus Abberger and Wolfgang Nierhaus, The Ifo Business Cycle Clock: Circular Correlation with the Real GDP, September 2010

3180 Walter Krämer and Gerhard Arminger, "True Believers" or Numerical Terrorism at the Nuclear Power Plant, September 2010

3181 Bernard M.S. Van Praag, Dmitri Romanov and Ada Ferrer-i-Carbonell, Happiness and Financial Satisfaction in Israel. Effects of Religiosity, Ethnicity, and War, September 2010

3182 Dimitrios Koumparoulis and Paul De Grauwe, Public Capital, Employment and Productivity: An Empirical Investigation for Greece, September 2010

3183 John Whalley and Tanmaya Shekhar, The Rapidly Deepening India-China Economic Relationship, September 2010

3184 Andreas Schäfer and Thomas Steger, History, Expectations, and Public Policy: Economic Development in Eastern Germany, September 2010

3185 Thomas Eichner and Marco Runkel, Subsidizing Renewable Energy under Capital Mobility, September 2010

3186 Konstantinos Angelopoulos and James Malley, Fear of Model Misspecification and the Robustness Premium, September 2010

3187 Philip E. Graves, A Note on the Design of Experiments Involving Public Goods, September 2010

3188 Glenn Ellison, How does the Market Use Citation Data? The Hirsch Index in Economics, September 2010

3189 Barbara Hanel and Regina T. Riphahn, The Employment of Mothers - Recent Developments and their Determinants in East and West Germany, September 2010

3190 Alexander Haupt and Silke Uebelmesser, Integration, Mobility, and Human Capital Formation, September 2010 